\title{
'n Ondersoek na fasette van leerders in 'n privaat skool se studieoriëntasie en die verband daarvan met wiskunde- prestasie $^{1}$
}

\author{
J.G. Maree \\ Departement Kurrikulumstudies, Fakulteit Opvoedkunde, Universiteit van Pretoria \\ E-pos: kobus.maree@up.ac.za \\ G. Crafford \\ Departement Statistiek, Fakulteit Natuur- en Landbouwetenskappe, Universiteit van Pretoria
}

\begin{abstract}
UITTREKSEL
Ontoereikende prestasie in wiskunde is 'n enorme probleem in postapartheid Suid-Afrika. In die onderhawige artikel word hierdie verskynsel bespreek en word etlike moontlike redes hiervoor aangedui. Die primêre doel van hierdie studie is onder meer die verkenning van die verband tussen leerders in 'n Suid-Afrikaanse privaat skool se wiskundeprestasie en hul studieoriëntasie. Die Studieoriëntasievraelys in Wiskunde (SOW) is vir die doel van die studie as meetinstrument gebruik. Daar is bevind dat die proporsie leerders met beter studiegewoontes hoër is by vroulike leerders as by manlike leerders. Dit wil voorkom of wiskundeangs, probleemoplossingsgedrag, asook studieomgewing betekenisvolle voorspellers van leerderprestasie in die betrokke privaatskoolkonteks is. Laastens blyk dit dat wiskundeprestasie toeneem met 'n afname in wiskundeangs, maar dat hierdie toename nielineêr is en afplat namate wiskundeangs afneem.
\end{abstract}

\begin{abstract}
An investigation into facets of study orientation of learners in a private school and its link with achievement in mathematics

Inadequate achievement in mathematics appears to be a major problem in post-apartheid South Africa. In the current article this phenomenon is discussed and possible reasons are indicated. The primary aim of the article is an investigation into the relationship between achievement in mathematics of learners in a South African private school and their study orientation. For this purpose the Study Orientation Questionnaire in Mathematics (SOM) was used as a measuring instrument. It was found that the proportion of learners with more adequate study habits is higher in the case of female learners than in the case of male learners. Mathematics anxiety, problem-solving behaviour and study environment appear to be significant predictors of learner achievement in the private school context corncerned. Lastly, it seems as if mathematics achievement increases with a decrease in mathematics anxiety. However, this decrease is not linear and tapers off with a decrease in mathematics anxiety.
\end{abstract}

\section{INLEIDING}

Leerders word daagliks gekonfronteer met toenemende eise om massas inligting te verwerk en te kan toepas in 'n Suid-Afrikaanse samelewing waar die werkloosheidsyfer buitengewoon hoog is. Folscher ${ }^{2}$ het die volgende in hierdie verband te sê: "[South Africa (SA) provides] a context where unemployment stands at $36 \%$ and where child poverty is estimated at $40 \% \ldots$. Mkhize $^{3}$ skat die werkloosheidsyfer is dalk so hoog as $40 \%$. Hierdie eise verplig Suid-Afrikaanse onderwysinstellings (primêr, sekondêr, maar ook tersiêr) om deurlopend te besin oor hul aard en doelstellings in ' $\mathrm{n}$ poging om leerders toereikend voor te berei op 'n veranderende wêreld. Leerders behoort immers deur onderwysinstellings voorberei te word om lewensuitdagings toereikend te hanteer. ${ }^{4} 5$

Kenners spreek toenemend hul kommer uit oor aspekte van UGO, asook oor leerderprestasie, sowel in die algemeen as wiskundeprestasie in besonder. Enkele van hierdie opmerkings, wat moontlik van toepassing is op die huidige artikel, word ter inleiding bespreek.

Volgens Yeld ${ }^{6}$ word Suid-Afrikaanse leerders "dommer en dommer". Yeld reken dat sowel leerders as hul onderwysers verstandelik agteruitgaan, aangesien die kognitiewe uitdagings wat aan hulle gestel word, toenemend afneem. Lolwana ${ }^{7}$ beklemtoon dit dat bepaalde vaardighede slegs deur memorisering verwerf kan word. Pistorius ${ }^{8}$ beklemtoon dit dat daar landwyd kommer bestaan oor die wiskundige en taalvaardigheid van nuwe eerstejaarstudente. Schlemmer' wys weer daarop dat 'n halfmiljoen Suid-Afrikaanse leerders steeds geen klaskamers het nie, terwyl slegs $5 \%$ van die matrikulante wiskunde in die hoër graad slaag en $32 \%$ in die standaardgraad. Hy wys verder daarop dat $20 \%$ van alle skole nie eens wiskunde as vak aanbied nie en meen dat die verbeteringe wat hul oor die afgelope aantal jaar ten opsigte van die matriekslaagsyfer gemanifesteer het, bloot kosmeties is, aangesien die aantal matrikulante wat matriek skryf, tussen 1998 en 2004 met sowat 17\% gedaal het.

Pandor ${ }^{10}$ wys daarop dat slegs 30 swart leerders in die WesKaap in 2003 wiskunde in die hoër graad geslaag het. Sy verklaar voorts: "Our interventions in mathematics, science and technology should gradually improve the performance of poor and marginalised learners in general, and girls in particular." Navorsing bring verder aan die lig dat digby $40 \%$ van alle eerstejaarstudente jaarliks hul eerstejaar druip. Hulle is by uitstek leerders uit tradisioneel benadeelde gemeenskappe. ${ }^{11}$

Die instelling van sistemiese evaluasie op graad 3- en graad 6-vlak het meegebring dat leerders nou op 'n veel vroeër stadium geëvalueer word ten opsigte van hul basiese vaardighede, iets wat meebring dat tydig ingegryp kan word ten einde remediëring te fasiliteer in gevalle waar dit nodig sou blyk. Die eerste graad 3 -evaluering in 2001 het aan die lig gebring dat leerders veral ten opsigte van syfervaardigheid ontoereikend gepresteer het en dat aggressiewe ingryping nodig is ten einde die situasie te verbeter. ${ }^{12}$ Leerders het ' $n$ gemiddelde persentasie van $30 \%$ behaal. ${ }^{13}$

Dit blyk dus dat die besef posgevat het dat vroeë assessering 
en ingryping onontbeerlik is indien gehoop wil word op 'n verbetering in die prestasie van graad 12-leerders, by uitstek in wiskunde. Die huidige artikel is dan ook gebaseer op die aanname dat vroeë assessering en ingryping (spesifiek in wiskunde) essensieel is in 'n poging om wiskundeprestasie in Suid-Afrika te verbeter. Soos die outeurs hierbo aantoon, maak die toenemende klem op die verwerwing van bepaalde uitkomste dit onontbeerlik vir onderwysers om deurlopend te besin oor die effektiwiteit van hul eie onderrig, by uitstek teen die verwysingsraamwerk van Uitkomsgerigte Onderrig (UGO) in Suid-Afrika (vir die doel van die onderhawige artikel word gefokus op die vak "wiskunde"). Navorsing oor assesseringsmeganismes wat spesifiek vir assessering in wiskunde gebruik kan word, is esensieel, maar dit is ewe belangrik om voortdurend navorsing te doen oor die effektiwiteit van hierdie instrumente.

Daar word vervolgens gefokus op enkele aspekte van wiskundeprestasie in Suid-Afrika sedert 1994.

\section{ASPEKTE VAN WISKUNDEPRESTASIE IN SUID-AFRIKA SEDERT 1994}

\section{Lae slaagsyfer in wiskunde in Suid-Afrika}

Alhoewel onderwys en opleiding in postapartheid Suid-Afrika getransformeer word, bly die druipsyfer vir wiskunde op skool onaanvaarbaar hoog. ${ }^{14}{ }^{15}$ Slegs ongeveer $20 \%$ van alle SuidAfrikaanse tersiêre studente gradueer ${ }^{16}$ en studente op die terrein van die wetenskap en handel toon die hoogste druipsyfers.

\section{Hoe vergelyk Suid-Afrikaanse leerders se wiskunde- prestasie met dié van ander leerders wêreldwyd?}

Die TIMMS-R-ondersoek na wêreldwye tendense in skolastiese prestasie in wiskunde en wetenskap het bevestig dat SuidAfrikaanse wiskundeleerders se prestasie beduidend swakker was as dié van die meeste ander deelnemende lande wat deur toetse in basiese wiskundevaardighede gemeet is. ${ }^{17}$ Suid-Afrika het selfs beduidend swakker gevaar as die twee ander Afrikalande wat aan die opname deelgeneem het, naamlik Marokko en Tunisië. Suid-Afrikaanse leerders het veral gesukkel met taalprobleme. Oor die algemeen het die leerders baie probleme ervaar met die kommunikering van hul antwoorde in die taal van die toets (Engels) en hulle het ook getoon dat hul nie oor die vereiste basiese wiskundige kennis beskik het nie.

\section{SA leerders sukkel met probleemoplossing}

Navorsing dui aan dat baie leerders in Suid-Afrikaanse skole nie die nodige kennis en vaardighede vir doeltreffende leer en probleemoplossing voldoende bemeester het nie. Leerders gee dikwels blyke van ontoereikende, oppervlakkige "papegaaikennis" van basiese begrippe. ${ }^{18} 19$

\section{Pogings om te verklaar waarom SA leerders so sukkel in wiskunde}

Wiskundeprestasie verskil aansienlik ten opsigte van 'n aantal faktore wat kenmerkend is van die tradisionele benadering tot die onderrig in en aanleer van wiskunde. Een sodanige faktor is 'n ontoereikende studieoriëntasie wat die volgende insluit: 'n neiging om minder huiswerk te doen, gebrek aan motivering, negatiewe gesindheid teenoor die studie van wiskunde, ontoereikende probleemoplossingsvaardighede in wiskunde, gebrekkige vermoë om krities te dink in wiskunde en swak inligtingsprosesseringsvaardighede. Die gebruik van effektiewe leer en studiestrategieë is 'n belangrike faktor in die bepaling van sukses in wiskunde op skool en op universitêre vlak. ${ }^{20}$ Toereikende studieoriëntasie in wiskunde (wat gegrond is op 'n probleemgesentreerde benadering tot die onderrig in en die aanleer van wiskunde) is 'n beduidende faktor in die bepaling van sukses op skool en universiteitsvlak. ${ }^{21}$. Die meer tradisionele benadering in Suid-Afrika word geassosieer met papegaaileerwerk, leer sonder die nodige insig, 'n gebrek aan kreatiwiteit, 'n tendens om te onderwysgeoriënteerd te wees en 'n gebrek aan leerderaktiwiteit. ${ }^{22}$ Die probleemgesentreerde benadering is weer op die volgende hoekstene gebaseer: ' $n$ sin vir syfervaardigheidsontwikkeling, woordprobleme, sosiale interaksie, leerderaktiwiteit en ontdekkende leer. Kinders leer wiskunde optimaal wanneer hulle hul idees, opinies en menings met sowel ander leerders as onderwysers deel; wiskunde verduidelik aan ander leerders, luister na ander leerders wat wiskunde verduidelik; besef dat dit elke leerder se reg is om foute te maak; probleme uit die werklike lewe oplos; doen in plaas van om slegs te luister; toegelaat word om saam in groepe werk; en wiskunde bemeester en aanleer wanneer dit vir hulle sin maak.

Die mondelinge tradisie (wat vooropgestel word met die tradisionele benadering) veronderstel onder andere dat kommunikasie van "bo" na onder is met min vrae van "onder". Die fokus is op luister, memorisering en die herroeping van inligting. Kognitiewe prosesse van 'n hoër orde (byvoorbeeld strategiese beplanning, hipotesetoetsing en die kritiese evaluering van resultate) is nie ontwikkel nie. Die leerders se ervaring van onderrig en leer het die verwerwing van 'n toereikende studieoriëntasie in wiskunde belemmer en aanleiding gegee tot die gevolgtrekking dat wiskunde 'n simboliese, abstrakte en irrelevante vak is.

Verskeie ondersteunende hipoteses is voorgestel in 'n poging om ontoereikende wiskundeprestasie te verklaar en sluit die volgende in: swak sosio-ekonomiese agtergrond van leerders (swak aanmoediging om tuis te studeer), gebrek aan geskikte leerder-ondersteuningsmateriaal, armoedige skoolomgewings, algemene swak gehalte van onderwys en onderrig (insluitend swak vakkennis en swak motivering), taalmedium (dikwels nie dieselfde as die leerders se moedertaal nie) en 'n ontoereikende studieoriëntasie.

\section{Pogings om SA leerders se wiskunde te verbeter}

Gedurende die laaste paar dekades het 'n oormaat nasionale planne in ontwikkelende lande ontstaan om voorsiening te maak vir ekonomiese ontwikkeling. ${ }^{23}$ Suid-Afrika het ook as gevolg van die nuwe politieke bedeling van 1994 dieselfde tendens getoon en die probleemgesentreerde benadering in wiskunde het aandag geniet as ' $n$ alternatief vir die meer tradisionele benadering in Suid-Afrika.

Wiskunde-onderwys in Suid-Afrika noodsaak die implementering van 'n realistiese benadering tot die onderrig in en aanleer van wiskunde. Navorsing dui ook daarop dat 'n strategiegebaseerde benadering tot die onderrig en leer van wiskunde (dit wil sê, leerders bemeester 'n verskeidenheid probleemoplossingstrategieë wat in die klaskamer onderrig word), ${ }^{24}$ 'n bydrae daartoe kan lewer om wiskundeprestasie te verbeter, ${ }^{25}$ by uitstek in tradisioneel benadeelde klaskamers.

Daar is verder afdoende bewys dat talle leerders uit tradisioneel swart woonbuurte na stadskole stroom, iets wat meebring dat hierdie skole dit toenemend moeiliker vind om ervare onderwysers te werf en te behou. ${ }^{26}$ Vermoënde voormalige model C-skole beskik verder oor die finansies om bykomende onderwysers te besoldig, terwyl townshipskole nie oor hierdie weelde beskik nie. 


\section{UGO en wiskundeprestasie}

Sedert die instelling van demokrasie ondergaan die SAonderwysstelsel omvattende herstrukturering. 'n Stelsel van UGO is geformuleer om saam te val met die instelling van demokrasie in Suid-Afrika in 1994. Hierdie onderwysstelsel is in 1998 ingestel en in 2001 gewysig. ${ }^{27}$ Dit gaan van die standpunt uit dat alle leerders die vermoë het om te slaag en dit fokus op die verwerwing van kennis, vaardighede, waardes en gesindhede anders as die tradisionele stelsel wat by uitstek op inhoudbemeestering gebaseer was. Volgens hierdie paradigma word van onderwysers verwag om wiskunde uit die werklike lewe in klaskamers in te stel en leerders te help om vaardighede te verwerf wat hulle sal voorberei om lewenslange leerders en kritiese denkers te word. In Suid-Afrika word beoog dat hierdie nuwe kurrikulum (in die omgangstaal bekend as Kurrikulum 2005, afgekort as C2005 en gebaseer op beginsels soos leerdergesentreerdheid, formatiewe assessering, integrasie en kritiese denke - wat wêreldwyd baie steun verwerf het) die waardes en beginsels van die nuwe Suid-Afrika moet weerspieël.

Nietemin lyk dit nie of die UGO-stelsel bevredigende resultate oplewer nie. Onlangse navorsing het getoon dat die oorgrote meerderheid van graad 6-leerders in die Wes-Kaap (gewoonlik een van die toppresterende provinsies in Suid-Afrika) nie eens die geletterdheids- en syferkennisvlakke wat van graad 4-leerders verwag word, bereik het nie. ${ }^{28}$ Van die ongeveer 35000 graad 6leerders wat in die Wes-Kaap in 2003 getoets is, het slegs $15.6 \%$ die syferkennistoets geslaag. Die resultate het boonop die ontsaglike diskrepansie tussen die prestasies van die vorige model C-skole (met hoofsaaklik blanke leerders) en dié van voorheen agtergeblewe skole (met swart leerlinge) bevestig. ${ }^{29}$ Onderwysers dwarsoor die land wat geensins verantwoordelik was vir of betrokke by die ontwikkeling van die nuwe kurrikulum, stem saam dat leerders in graad 10 in die Verdere Onderwys- en Opleidingsfase (VOO-fase) toenemend swakker resultate behaal, dat 'n onaanvaarbaar hoë persentasie leerders wiskunde druip en die vak in die middel van die jaar laat vaar. ${ }^{30}$

\section{NAVORSINGSONTWERP}

Twee aanvullende benaderings, naamlik 'n kwantitatiewe en kwalitatiewe benadering, is in die onderhawige navorsing geïmplementeer ('n KWAN-kwal-benadering). Die (beperkte) kwalitatiewe deel van die studie behels die kwalitatiewe ontleding van gesprekke met enkele onderwysers verbonde aan die betrokke skool, terwyl 'n tersaaklike literatuuroorsig van 'n aantal primêre en sekondêre wetenskaplike bronne onderneem is. Die kwantitatiewe deel van die studie behels enersyds 'n analise van die prestasies van leerders in die Studieoriëntasievraelys in Wiskunde (SOW) ${ }^{31}$ en andersyds die tref van statistiese vergelykings tussen die prestasie van die twee geslagsgroepe.

\section{Navorsingstyl: Oorsignavorsing}

Oorsignavorsing word in die onderhawige navorsing geïmplementeer. In hierdie tipe navorsing selekteer navorsers 'n steekproef respondente, pas vraelyste toe, samel inligting in oor veranderlikes wat hulle interesseer en gebruik die data om die eienskappe van 'n populasie te beskryf, byvoorbeeld houdings, gedrag, gewoontes en ander tipes inligting. ${ }^{32}{ }^{33}$ Data word op 'n spesifieke oomblik ingesamel met die doel om die aard van die omstandighede op daardie tydstip te bespreek, om standaarde te identifiseer waarteen bestaande omstandighede vergelyk kan word of om die verwantskappe tussen gebeure te bespreek.

\section{Steekproef}

Alle leerders in graad 7 in 'n "tipiese" Engelsmedium privaat skool in Gauteng is in die steekproef ingesluit (80 seuns en 47 dogters). Onder "tipies" verstaan die navorsers in die betrokke konteks die volgende: ${ }^{34}$

a. Die voertaal is Engels.

b. Skoolfondse is aansienlik hoër as in staatskole (leerders is dus oorwegend afkomstig uit 'n relatief hoë sosioekonomiese milieu).

c. Leerders is oorwegend Engelssprekend.

d. 'n Betekenisvolle persentasie leerders is swart.

e. 'n Relatief kleiner persentasie leerders is Afrikaanssprekend.

f. Klasse is oorwegend kleiner as in "tipiese" staatskole (verhouding onderwyser:aantal leerlinge $=$ ca. 1:25, terwyl die ideaal in staatskole op ca. 1:35 gestel word).

g. Aansienlik beter opleidings- en ander fasiliteite in vergelyking met staatskole.

h. 'n Aansienlik beter gekwalifiseerde en meer gemotiveerde onderwyserskorps.

i. Gemiddeld meer manlike onderwysers in vergelyking met staatskole.

\section{Metodologie}

\section{Reëlings}

Die onderhawige opname is op 5 Februarie 2004 gedoen (leerders is gevra om die $\mathrm{SOW}^{35}$ te voltooi en om demografiese inligting te verskaf). Die doel van die toetsing is aan leerders en hul ouers (waar moontlik), asook aan die skoolhoof verduidelik en betrokkenes is meegedeel dat leerders se tellings en wiskundepunte vir navorsingsdoeleindes gebruik sou word.

\section{Etiese aspekte}

Skriftelike toestemming is versoek en verkry van die Skoolbeheerliggaam en ook van leerders se ouers vir die uitvoering van die navorsing en publisering van die bevindings. Die versekering is gegee dat geen individu geïdentifiseer sou word nie.

\section{Beperkinge van die studie}

Dit was ' $n$ beperkte plaaslike studie en die bevindings in hierdie artikel het beperkte veralgemeningswaarde.

\section{Hoofnavorsingsvraag en voortvloeiende hipoteses}

Die aard van leerders in 'n privaat skool se studieoriëntasie en die verband daarvan met wiskundeprestasie kan as die primêre navorsingsprobleem van die onderhawige navorsing beskou word. Vir die doeleindes van hierdie artikel fokus die outeurs op die volgende vier hipoteses:

$\mathrm{H}_{01}$ : Daar bestaan geen verwantskap tussen geslag en prestasie in Veld 3 van die SOW (vir die doel van die artikel, word verderaan slegs verwys na velde (kyk Tabel 4 ) in terme van swak, gemiddeld en bogemiddeld).

$\mathrm{H}_{\mathrm{a} 1}$ : Daar bestaan 'n statisties beduidende verwantskap tussen geslag en prestasie in Veld 3 van die SOW (in terme van swak, gemiddeld en bogemiddeld).

$\mathrm{H}_{02}$ : Daar is geen verskil tussen die gemiddelde tellings van seuns en dogters in die vyf SOW-velde, asook in wiskunde nie.

$\mathrm{H}_{\mathrm{a} 2}$ : Daar is ' $\mathrm{n}$ statisties beduidende verskil tussen die gemiddelde tellings van seuns en dogters in die vyf velde, asook in wiskunde. 
$\mathrm{H}_{03}$ : Daar is geen korrelasie tussen seuns en dogters onderskeidelik se prestasies in die vyf velde nie.

$\mathrm{H}_{\mathrm{a} 3}$ : Daar is 'n statisties betekenisvolle korrelasie tussen seuns en dogters onderskeidelik se prestasies in die vyf velde.

$\mathrm{H}_{04}$ : Daar is geen korrelasie tussen seuns, dogters en die totale groep se prestasie in die vyf velde enersyds en wiskundeprestasie andersyds.

$\mathrm{H}_{\mathrm{a} 4}$ : Seuns, dogters en die totale groep se prestasie in die vyf velde enersyds korreleer betekenisvol met wiskundeprestasie andersyds.

Die volgende navorsingsvrae sal ook ondersoek word:

a. Is prestasies in die vyf SOW-velde voorspellers van wiskundeprestasie?

b. Wat is die aard van die verwantskap tussen wiskundeangs en wiskundepretasie?

\section{Veranderlikes}

Die afhanklike veranderlikes wat vir die doel van hierdie ondersoek gebruik is, is Graad 7-leerders se prestasie in die vyf SOW-velde; asook hul wiskundeprestasie.

Die onafhanklike veranderlike is geslag. Prestasie in die vyf SOW-velde is as onafhanklike veranderlikes gebruik by die voorspelling van wiskundeprestasie

\section{Dataverwerkingsprosedures}

Enkele statistiese prosedures is uitgevoer om die hipoteses te ondersoek. Hierdie prosedures sluit in:

a. Frekwensies, gemiddeldes en standaardafwykings (beskrywende statistiek) is bereken.

b. Student se t-toets is bereken om die verskille tussen die prestasies van die geslagsgroepe se gemiddeldes verder te ondersoek.

c. Die Chi-kwadraat-prosedure is gebruik om te toets vir enkele verwantskappe tussen die geslagsgroepe se gekategoriseerde prestasies.

d. Pearson-korrelasiekoëffisiënte is per geslagsgroep bereken tussen die SOW-velde, asook tussen SOW-velde en wiskundeprestasie onderling, per groep en in geheel.

e. Regressie-analise is gebruik om te kyk of prestasies in die vyf subtoetse van die SOW voorspellers van wiskundeprestasie is.

\section{Meetinstrument: Die Studieoriëntasievraelys in Wiskunde (SOW)}

Die SOW is deur die RGN ontwikkel en gestandaardiseer om Suid-Afrikaanse leerders vanaf graad 7 tot 12 se studieoriëntasie in wiskunde te meet. ${ }^{36}$ Dié vraelys bied aan onderwysers en voorligters die geleentheid om meer inligting te bekom oor leerders as bloot net kognitiewe vakprestasie. Aangesien die setel van ontoereikende wiskundeprestasie aspekte behels wat buite die kognitiewe terrein val, is die fokus van hierdie meetinstrument om 'n ondersteunende affektiewe onderbou daar te stel vir kognitiewe vakprestasie in wiskunde

Die SOW bestaan uit ses subskale van 92 stellings wat verband hou met hoe individue voel of optree ten opsigte van aspekte van hulle wiskundeprestasies. Die toets is tussen 1994 en 1997 ontwikkel deur die Raad vir Geesteswetenskaplike Navorsing, ${ }^{37}$ gebaseer op response van 3013 Suid-Afrikaanse hoërskoolleerders. Die normsteekproef was verteenwoordigend van alle Suid-Afrikaanse hoërskoolleerders. Studiehouding (14 items) sluit in gevoelens (subjektiewe en objektiewe belewenisse) en houdings jeens wiskunde en het betrekking op leerders se motivering, verwagting en belangstelling ten opsigte van wiskunde. Wiskundeangs (14 items) het betrekking op 'n "ongemaklike" gevoel oor wiskunde en word gesien in gedrag soos oormatige sweet, uitvee van korrekte antwoorde en die onvermoë om wiskundige begrippe te formuleer. Studiegewoontes (17 items) behandel die toepassing van verworwe, konsekwente en effektiewe studiemetodes. Probleemoplossingsgedrag (18 items) sluit in kognitiewe en metakognitiewe strategieë in wiskunde. Studie-omgewing (13 items) verwys na aspekte verwant aan die sosiale, fisiese en beleefde omgewing. Inligtingverwerking (16 items) behels algemene en spesifieke leerprosesse, samevatting- en leesstrategieë, kritiese denke en begripstrategieë soos die optimale gebruik van sketse, tabelle en diagramme. Dié subskaal is slegs op graad 10-,11- en 12-leerders van toepassing.

Die leerder moet elke item bepunt volgens 'n 5-puntresponsformaat geanker deur $0=$ Selde en $4=$ Byna altyd. Van die items word 46 positief bewoord en 46 negatief, om geykte reaksiepatrone te voorkom. Inligting oor verkose antwoorde kan na persentielrange omgeskakel word. Die vertolking van 'n profiel word voorgestel as 70-100\% (toereikende studie-oriëntasie), 40$69 \%$ (neutraal, maar kan bydra tot 'n toereikende of ontoereikende studieoriëntasie), en $0-39 \%$ (ontoereikende studieoriëntasie).

Betroubaarheidskoëffisiënte vir die verskillende subskale het gewissel van 0.70 to 0.80 en vir die vraelys as 'n geheel van 0.89 tot 0.95 .

Die oorkoepelende doel van die SOW kan soos volg saamgevat word:

- Uitkenning: leerders met 'n ontoereikende studieoriëntasie in wiskunde kan met behulp van die SOW uitgeken word.

- Begrip: die uitslag van die SOW kan onderwysers en hulpverleners help om leerders met swak akademiese wiskundeprestasie beter te begryp.

- Hulpverlening: resultate kan gebruik word om leerders te help om hul studieoriëntasie in wiskunde te verbeter en gevolglik hul potensiaal op ' $n$ hoër vlak te verwesenlik.

Verhoudings en verskille op die 5\%-vlak van betekenis is as statisties betekenisvol beskou, tensy anders vermeld.

\section{RESULTATE}

TABEL 1 Frekwensies in terme van geslag en moedertaal en beskrywende statistiek in terme van ouderdom (demografiese veranderlikes)

\begin{tabular}{|c|c|c|}
\hline \multicolumn{2}{|c|}{ Geslag } & \\
\hline Seuns & Dogters & Totaal \\
\hline 80 & 47 & 127 \\
\hline \multicolumn{2}{|c|}{ Moedertaal } & \\
\hline Engels & Afrikaans & \\
\hline 116 & 11 & 127 \\
\hline \multicolumn{2}{|c|}{ Ouderdomsgroep } & \\
\hline $11-12$ jaar & $13-14$ jaar & 127 \\
\hline 110 & 17 & \\
\hline
\end{tabular}


TABEL 2 Gebeurlikheidstabel van geslag en prestasievlak in Veld 3 (gekategoriseerd) van die SOW (p-waarde vir c²)

\begin{tabular}{|c|c|c|c|c|c|}
\hline \multirow{3}{*}{ Karakteristiek } & \multicolumn{3}{|c|}{ Prestasievlak } & & \\
\hline & \multirow[t]{2}{*}{ Swak } & \multirow[t]{2}{*}{ Gemiddeld } & \multirow[t]{2}{*}{ Bo-gemiddeld } & \multicolumn{2}{|c|}{$\begin{array}{c}\mathbf{p} \\
\text { effekgrootte tussen hakies } \\
\text { vir beduidende waarde }\end{array}$} \\
\hline & & & & Statistiek & (tweekantig) \\
\hline & \multicolumn{3}{|c|}{ Veld 3 (Studiegewoontes) } & & \\
\hline \multicolumn{6}{|l|}{ Geslag } \\
\hline Manlik & $17(21.3 \%)$ & $40(50.0 \%)$ & $23(28.8 \%)$ & & \\
\hline Vroulik & $8(17.02 \%)$ & $14(29.79 \%)$ & $25(53.19 \%)$ & $\mathrm{Chi}^{2}(2)=7.79$ & $0.020 *(0.25)$ \\
\hline Totaal & $25(19.69 \%)$ & $54(42.52 \%)$ & $48(37.80 \%)$ & & \\
\hline
\end{tabular}

*: betekenisvol op die 5\%-peil van betekenis

TABEL 3 Tweekantige t-toets-vergelykings tussen seuns $(M ; n=80)$ en dogters $(V ; n=47)$

\begin{tabular}{|c|c|c|c|c|c|}
\hline SOW-veld & Geslag & $\bar{x}$ & SA & Statistiek & p \\
\hline \multirow{2}{*}{ Studiehouding } & $\mathrm{M}$ & 57.988 & 26.306 & $t(125)=1.19$ & 0.237 \\
& $\mathrm{~V}$ & 51.915 & 30.178 & & 0.173 \\
\hline \multirow{2}{*}{ Wiskundeangs } & $\mathrm{M}$ & 69.563 & 23.344 & $t(125)=1.37$ & 0.078 \\
& $\mathrm{~V}$ & 62.851 & 31.528 & & \\
\hline \multirow{2}{*}{ Studiegewoontes } & $\mathrm{M}$ & 56.988 & 26.358 & $t(125)=-1.78$ & 0.946 \\
\hline Probleemoplos- & $\mathrm{V}$ & 65.809 & 28.169 & & \\
singsgedrag & $\mathrm{M}$ & 47.063 & 28.716 & & \\
\hline \multirow{2}{*}{ Studie-omgewing } & $\mathrm{V}$ & 76.702 & 28.72 & & \\
& $\mathrm{~V}$ & 73.851 & 20.66 & & \\
\hline \multirow{2}{*}{ Wiskundepunt } & $\mathrm{M}$ & 68.58 & 10.04 & $t(125)=0.40$ & \\
& $\mathrm{~V}$ & 66.60 & 11.58 & & 0.689 \\
\hline
\end{tabular}

TABEL 4 Pearson-korrelasiekoëffisiënte van die subtoetse vir seuns $(n=80)$

\begin{tabular}{|l|c|c|c|c|c|}
\hline SOW-veld & $\mathbf{1}$ & $\mathbf{2}$ & $\mathbf{3}$ & $\mathbf{4}$ & $\mathbf{5}$ \\
\hline Studiehouding (1) & & & & & \\
\hline Wiskundeangs (2) & $0.45^{*}$ & & & & \\
\hline Studiegewoontes (3) & $0.71^{*}$ & $0.42^{*}$ & & & \\
\hline Probleemoplossingsgedrag (4) & $0.58^{*}$ & $0.23^{*}$ & $0.63^{*}$ & & \\
\hline Studie-omgewing (5) & $0.55^{*}$ & $0.69^{*}$ & $0.39^{*}$ & 0.21 & \\
\hline
\end{tabular}

*: betekenisvol op die 5\%-peil van betekenis

TABEL 5 Pearson-korrelasiekoëffisiënte van die subtoetse vir dogters $(n=47)$

\begin{tabular}{|l|c|c|c|c|c|}
\hline SOW-veld & $\mathbf{1}$ & $\mathbf{2}$ & $\mathbf{3}$ & $\mathbf{4}$ & $\mathbf{5}$ \\
\hline Studiehouding (1) & & & & & \\
\hline Wiskundeangs (2) & 0.22 & & & & \\
\hline Studiegewoontes (3) & $0.81^{*}$ & 0.03 & & & \\
\hline Probleemoplossingsgedrag (4) & $0.57^{*}$ & -0.03 & $0.71^{*}$ & & \\
\hline Studie-omgewing (5) & $0.44^{*}$ & $0.63^{*}$ & 0.17 & 0.16 & \\
\hline
\end{tabular}

*: betekenisvol op die 5\%-peil van betekenis 
TABEL 6 Pearson-korrelasiekoëffisiënte van subtoetse met wiskundeprestasie vir geslagte, asook gesamentlik

\begin{tabular}{|l|c|c|c|c|c|}
\hline $\begin{array}{l}\text { SOW-subtoets } \rightarrow \\
\text { Wiskundeprestasie } \downarrow\end{array}$ & $\mathbf{1}$ & $\mathbf{2}$ & $\mathbf{3}$ & $\mathbf{4}$ & $\mathbf{5}$ \\
\hline Seuns (n=80) & $0.40^{*}$ & $0.38^{*}$ & $0.37^{*}$ & $0.38^{*}$ & $0.45^{*}$ \\
\hline Dogters (n=47) & 0.12 & $0.37^{*}$ & 0.09 & 0.15 & 0.25 \\
\hline Totale groep (n=127) & $0.29 *$ & $0.38^{*}$ & $0.24 *$ & $0.29^{*}$ & $0.37^{*}$ \\
\hline
\end{tabular}

*: betekenisvol op die 5\%-peil van betekenis

TABEL 7 Regressiemodel van die SOW en wiskundeprestasie van die graad 7-groep

\begin{tabular}{|c|c|c|c|c|}
\hline \multirow[b]{2}{*}{ SOW-subtoets } & \multirow{2}{*}{$\begin{array}{c}\text { Parameter- } \\
\text { skatting }\end{array}$} & \multicolumn{2}{|c|}{ Bepaaldheidskoëffisiënt } & \multirow[b]{2}{*}{$p$} \\
\hline & & Parsiële $R^{2}$ & $\begin{array}{c}\text { Model/ } \\
\text { Kumulatiewe } \boldsymbol{R}^{2}\end{array}$ & \\
\hline Afsnit & 51.253 & & & $<.0001 *$ \\
\hline Wiskundeangs & 0.100 & 0.147 & 0.147 & $0.018^{*}$ \\
\hline Probleemoplossingsgedrag & 0.085 & 0.061 & 0.208 & $0.005^{*}$ \\
\hline Studie-omgewing & 0.078 & 0.014 & 0.222 & $0.140 * *$ \\
\hline Regressievergelyking & & $=51.25+.1(x$ & $.085\left(x_{2}\right)+.07\left(x_{3}\right)$ & \\
\hline
\end{tabular}

$x_{1}=$ Wiskundeangs; $x_{2}=$ Probleemoplossingsgedrag; $x_{3}=$ Studie-omgewing in die regressievergelyking

Persentasie van wiskundeprestasie wat deur die model verklaar word: $\mathrm{R}^{2}=22.16 \%$.

*:betekenisvol op die 5\%-peil van betekenis

**: betekenisvol op die $15 \%$-peil van betekenis

Alhoewel Studie-omgewing slegs op die 15\%-peil van betekenis betekenisvol is, lewer die bepaalde veld tog 'n bydrae tot die model, om welke rede dit wel by die model ingesluit word.

TABEL 8 Regressiemodel van wiskundeangs en wiskundeprestasie van die graad 7-groep

\begin{tabular}{|l|c|c|}
\hline SOW-subtoets & Parameter-skatting & $\boldsymbol{p}$ \\
\hline Afsnit & 53.83 & $<.0001^{*}$ \\
\hline Wiskundeangs (V8) & 0.339 & $0.017^{*}$ \\
\hline$\left(\right.$ V8) ${ }^{2}$ & -0.002 & 0.173 \\
\hline \multicolumn{2}{|c|}{} \\
\hline
\end{tabular}

Wiskundeangs $=x_{1} \mathrm{~V} 8=x^{2}$ in die regressievergelying.

*: betekenisvol op die 5\%-peil van betekenis

Persentasie variansie verklaar: $\mathrm{R}^{2}=15.97 \%$

Al wat in die onderhawige geval as belangrik geag was, was die verwantskap tussen angs en wiskundeprestasie. Geen voorspelling word hier gedoen nie; slegs die marginale effek word boonop hier ondersoek. 


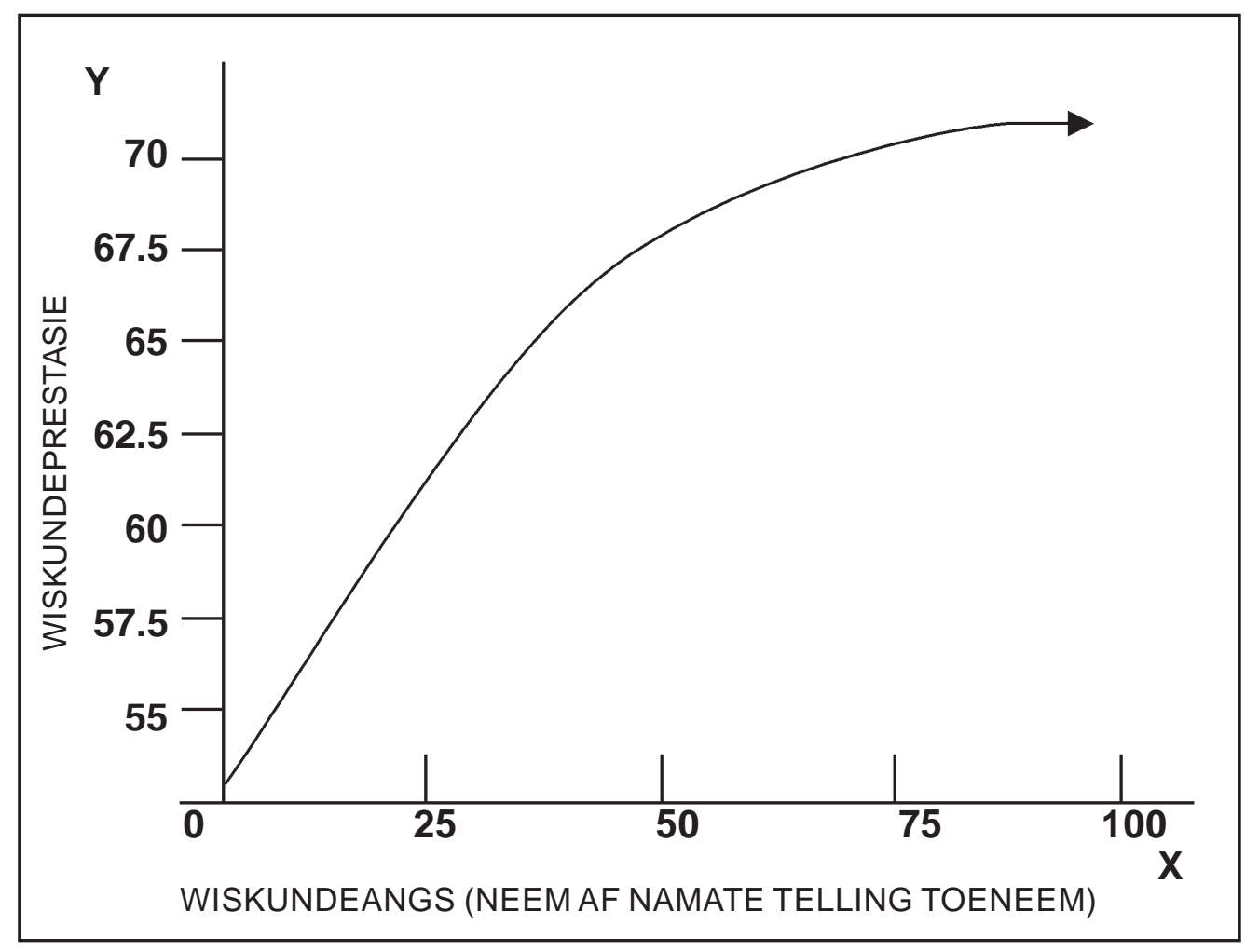

Figuur 1: Grafiese voorstelling van die verwantskap tussen wiskundeangs en wiskundeprestasie.

\section{BESPREKING VAN BEVINDINGS}

In Tabel 1 word die frekwensies in terme van skool, graad en geslag van die leerders wat aan die ondersoek deelgeneem het, uiteengesit. Dit blyk dat die navorsingsgroep oorwegend Engelssprekend is en dat die gemiddelde ouderdomme van leerders tipies van leerders in graad 7 is.

Inspeksie van Tabel 2 bring aan die lig dat daar ten opsigte van Veld 3 (studiegewoontes) 'n betekenisvolle verwantskap bestaan tussen geslag en prestasiekategorie in terme van swak (dit wil sê $<40 \%$ ), gemiddeld ( $40 \% \leq x \leq 70 \%$ ) en bogemiddeld $(>70 \%)$. Hipotese 1 word dus verwerp en die afleiding kan gemaak word dat prestasie in Veld 3 afhanklik is van geslag. Die proporsie leerders met bogemiddelde studiegewoontes is hoër by die vroulike leerders as in die geval van die manlike leerders. 'n Interessante verband wat uit Tabel 2 blyk, is dit dat 38\% van die leerders bogemiddeld gepresteer het in Veld 3. Waar 53\% van die dogters egter bogemiddeld gepresteer het (iets wat 'n definitiewe verwantskap aantoon), het slegs ca. $29 \%$ van die seuns bogemiddeld gepresteer. Dit kan dalk onder meer daaraan toegeskryf word dat die dogters in die bepaalde konteks wat in die onderhawige studie ondersoek word, oor toereikender studiegewoontes beskik as die seuns. Die effekgrootte van 0.25 dui nogtans nie op 'n prakties betekenisvolle verband nie, dit wil sê, hoewel daar sprake is van 'n statisties betekenisvolle verband, is hierdie verband nie in die praktyk belangrik nie.

Uit Tabel 3 blyk dit volgens die resultate van Student se ttoets $^{38}$ dat seuns en dogters se prestasies ten opsigte van geen veld betekenisvol verskil nie, asook nie in wiskunde self nie. Daar bestaan dus nie voldoende bewyse om hipotese 2 te verwerp nie. Dogters se studiegewoontes is nietemin op die 10\%-peil van betekenis toereikender as seuns s'n. Uit 'n kwalitatiewe, opvoedkundig-sielkundige perspektief, en hoewel die resultaat nie statisties betekenisvol is nie, is dit interessant dat die situasie net andersom was by Veld 1 (Studiehouding), waarin seuns weer beter presteer het as dogters.
Aangesien die items van elke veld opgestel is om 'n bepaalde faset of aspek van leerders se ingesteldheid jeens wiskunde te meet, behoort korrelasies tussen die verskillende velde oor die algemeen laag te wees. Uit Tabel 4 blyk dit dat die interkorrelasies in die geval van die seuns varieer tussen 0.71 (Veld 1 en Veld 3) en 0.21 (Veld 4 en Veld 5). Korrelasies is feitlik deurgaans betekenisvol en hipotese drie word feitlik deurgaans verwerp. Uit Tabel 5 blyk dit dat die interkorrelasies in die geval van die dogters varieer tussen - 0.03 (Veld 2 en Veld 4 ) en 0.81 (Veld 1en Veld 3). Korrelasies is in 50\% van die gevalle betekenisvol en hipotese drie word dus gedeeltelik verwerp. Inspeksie van Tabel 6 dui aan dat dit veral die seuns en die totale groep se prestasies in die velde is wat betekenisvol korreleer met wiskundeprestasie. Hipotese 4 word dus gedeeltelik verwerp.

Uit Tabel 7 blyk dit dat die regressiemodel kumulatief 22.2\% van die variasie in leerders se wiskundeprestasie voorspel. Inspeksie van die tabel toon dat veral Wiskundeangs $(\mathrm{p}<0.05)$, gevolg deur Probleemoplossingsgedrag $(\mathrm{p}<0.05)$ en in mindere mate hul Studie-omgewing $(\mathrm{p}<0.15)$ betekenisvolle voorspellers van leerders se wiskundeprestasie is.

Dit blyk uit die skets (Figuur 1) dat Wiskundeangs in graad 7 in 'n bepaalde mate wiskundeprestasie beïnvloed. Aanvanklik het 'n afname in Wiskundeangs (toename in $x$ ), 'n positiewe effek op wiskundeprestasie (dit wil sê, hoe minder Wiskundeangs leerders ervaar, hoe beter is hulle geneig om in wiskunde te presteer), maar hierdie tendens verswak namate wiskundeangs afneem ${ }^{39}$. In-diepte-onderhoude met die (uiters ervare) wiskundepersoneel verbonde aan die betrokke skool dui aan dat Wiskundeangs tydig en toepaslik deur die betrokke onderwyslui gehanteer word en dat leerders wat wiskundeprobleme kalm en met selfvertroue benader, meer geneig is om beter te presteer as andersins.

Sharma ${ }^{40}$ beskryf wiskunde as 'n bona fide tweede taal met eie alfabetiese simbole, woordeskat, sintaksis, grammatika en literatuur. Rothman en Cohen ${ }^{41}$ vra dan tereg waar die onderrig van die wiskundetaal in die wiskundekurrikulum inpas. In- 
diepte-onderhoude met onderwysers verbonde aan die skool waarna in die onderhawige studie verwys word, toon aan dat uiters ervare leerkragte betrokke is by taalonderrig en dat skakeling tussen wiskunde- en taalonderwysers optimaal verloop. Sentson ${ }^{42}$ beklemtoon die verband tussen leerders se vaardigheid in hulle eerste en tweede taal, terwyl Sibaya, Sibaya en Mugisha ${ }^{43}$ wys op die verband tussen taalvaardigheid en prestasie in wiskunde:

[B]lack secondary school pupils' performance in mathematics is significantly influenced by the command of the language of instruction. Furthermore, black pupils who have good command of mathematics language do better in mathematics than those who have poor command.

Die betrokke wiskundeleerkrag bevestig verder dat sy deurlopend aandag gee aan die onderrig van die spesifiek, tegniese taal van wiskunde. Hierdie onderwysers bevestig verder dat hulle uit hul pad gaan om die beginsels vervat in die SOW by leerders te fasiliteer, onder meer deur die uitnooi van kundiges na die skool om werkswinkels aan te bied.

\section{SLOTOPMERKINGS}

Talle leerkragte meen dat die instelling van UGO nie noodwendig die verwagte verbetering in leerders se wiskundeprestasie of hul studieoriëntasie in wiskunde meegebring het nie. Onderwysers dwarsoor die land stem saam dat leerders in graad 10 van die VOO-fase toenemend swakker resultate behaal met onaanvaarbare hoë persentasies leerders wat wiskunde druip en die vak in die middel van die jaar los - dit, in 'n land waar skattings aandui dat minder as $5 \%$ van die graad 12 -skoolverlaters 'n werk in die formele ekonomie sou kon vind in $2003 .{ }^{44}$ Slegs $9.4 \%$ van swart vroue het in 2002 matrikulasie-endossement (-vrystelling) behaal (blankes: $54 \%$ ) in vergelyking met $12.2 \%$ van die mans (blankes: $45 \%){ }^{45}$

Verskeie sake verdien kennelik indringend aandag indien gehoop word op oorbrugging van die huidige impasse, insluitend die ontoereikende toekenning van hulpmiddels aan swakker skole, uitgediende modelle in gebruik vir fondsinsameling by skole, die behoefte aan die "eliminering" van vermorsing van finansies (soos die hoë salarisse van amptenare en buitensporige konsultantkoste. $)^{46}$ Skoolhervorming is egter onmoontlik, tensy verandering teweeggebring word in (veral) die armoedige sosio-ekonomiese omstandighede van gemeenskappe waarin skole (veral dié in die plattelandse gebiede) hulle bevind. In 'n land wat ongeveer R10 biljoen op verdedigingsaangeleenthede spandeer, is dit inderdaad baie duidelik dat ' $n$ groot klemverskuiwing nodig is. ${ }^{47}$

In die lig van die voorgenoemde word daar ten slotte gefokus op enkele fasette van onderrig soos dit aan die skool in die onderhawige navorsing verloop, en wat waarskynlik met groot vrug deur ander skole toegepas kan word. Elke leerder beskik oor 'n volledige wiskunde-portefeulje wat 'n permanente rekord van die leerders se begrip van wiskundige konsepte, asook die stand van hul probleemoplossingsvaardighede fasiliteer. Hierdie portefeulje omvat onder meer inligting rakende die volgende fasette:

o Groepwerk.

o Individuele werk.

o Skriftelike werk.

o Gestandaardiseerde toetse.

o Probleemoplossingstrategieë.

o Metings van gesindheid en houding.

Diagnostiese ontleding of foute-analise van die leerder se werk in formele, informele of gestandaardiseerde assessering.

o Informele diagnostiese toetse, spesifiek deur die onderwysers opgestel om spesifieke konsepte of kombinasie van konsepte te toets.

o Gestandaardiseerde of formele diagnostiese toetse.

o Leerder se skoolboeke.

o Werksopdragte.

o Alle toetse, eksamenvraestelle en ander vorms van assessering en evaluering.

Affektiewe fasette wat geassesseer kan word, sluit onder meer die volgende in:

- Sigbare fasette: Die leerder se inisiatief, deelname aan klasbespreking en saamwerk in groepsverband.

- Verskuilde fasette: Die leerder se houding en gesindheid jeens wiskunde as vak; hul selfvertroue en deursettingsvermoë.

Laastens: Koöperatiewe leer vind deurlopend plaas en werkkaarte word deurlopend in wiskunde gebruik. Kenners word op 'n deurlopende basis deur die betrokke wiskundeleerkrag ge'kontrakteer' om navorsing uit te voer rakende fasette van haar wiskunde-onderrig.

Pandor $^{48}$ wys ten slotte daarop dat talle instansies wiskundiges juis op grond van hul probleemoplossingsvermoëns emplojeer. ${ }^{49}$ Internasionale navorsing dui boonop aan dat persone wat met wiskunde as vak aan tersiêre instansies afstudeer 'n veel beter kans staan om in diens geneem te word as persone wat sonder wiskunde afstudeer. Eersgenoemde groep persone verdien ook meer as laasgenoemde groep en word opgelei vir beroepe wat hulle in staat sal stel om entrepreneurs te word. Die aspekte waarna in hierdie artikel verwys word, behoort derhalwe deel te vorm van 'n omvattende nasionale strategie waarby alle onderwysers betrek behoort te word. Werkswinkels (waarby sowel onderwysers as ouers betrek behoort te word) oor die hantering en voorkoming van gebrek aan wiskunde-selfvertroue by leerders, asook oor die oorkoepelende doelstellings met wiskunde-onderrig, behoort vanselfsprekend deel te vorm van so 'n strategie. Die ontwikkeling van probleemoplossingsvaardighede, asook die verwerwing van konseptuele kennis en kennis rakende prosedures behoort deurlopend aandag te geniet en die verband tussen hierdie aspekte behoort aangetoon te word. 'n Raamwerk vir wiskunde-onderrig behoort daargestel te word, gebaseer op navorsing rakende sake soos:

o Die vraag na die wyse waarop leerders wiskunde leer. Dit behels enersyds ' $n$ ondersoek na die drie kognitiewe prosesse wat 'n bydrae lewer tot die konstruksie van wiskundige kennis, te wete voorstellings, refleksie en outomatisasie en andersyds 'n ondersoek na die wyse waarop leerders doen, waarneem, abstraheer, relasies tref, gevolgtrekkings maak en vaardighede ontwikkel.

o Die vraag na instruksiestrategieë. Navorsingsontwerpe behoort voorsiening te maak vir verwysing na gerelasionaliseerde denke, induktiewe en deduktiewe denke, asook cognitive modelling (hardop dink) as instruksiestrategie.

o Die betekenis van direkte instruksie, interaktiewe onderrig en koöperatiewe leer in wiskunde.

\section{VOETNOTE}

1. Opregte waardering word uitgespreek teenoor Dr. Mike van der Linde (Dept. Statistiek: UP) vir sy hulp met die dataverwerking, asook aan die leerders en onderwysers wat aan 
die studie deelgeneem het.

2. Folscher in Motala, S., Perry, H. (2001). The 2000 senior certificate examination. Quarterly Review of Education and Training in South Africa, 8(1), 1-12.

3. Mkhize, N. (2004). Social transformation and career marginalisation: theoretical and research implications. Paper read at the 10th Anniversary South African Congress of Psychology: Democratising the psyche, Durban, 20-23 September 2004

4. Chandler, H.A. (1989). Learning and conceptual understanding: a constructivist perspective. Educational Bulletin, 33(1), 317.

5. Department of Education (DoE). (1995). The white paper on education and training. Government Gazette. Number 16312. Pretoria: Government Printer.

6. Yeld in De Vries, A. (05.06.2005). Reuse-uittog knou townshipskole. Rapport, 20.

7. Lolwana in De Vries, A. (05.06.2005). Reuse-uittog knou townshipskole. Rapport, 20.

8. Pistorius in Rademeyer, A. (25.06.2005a). SA gaan ly oor te min geld vir hoër onderwys. Beeld, 7.

9. Schlemmer in Rademeyer, A. (25.06.2005b). Afrikaners al hoe vieser vir hul skole. Beeld, 7.

10. Pandor, N. (2004). Maths today and tomorrow. Toespraak van Minister Naledi Pandor by geleentheid van die opening van die 9e Wiskundekongres (AMESA). Potchefstroom, 1 Julie 2005.

11. Pandor in Mkhabela, M. (26.09.24). Failure rate for black students 'horrifying'. City Press, 6.

12. Bot, M. (2005). School education in South Africa: tracking change over ten years. Edusource Data News, 46, 1-10.

13. Department of Education. (2002). Draft education for all status report 2002: South Africa, incorporating country plans for 2002 to 2015. Pretoria: Goverment Printer.

14. Maree, J.G., Pretorius, A., Eiselen, R.E. (2003). Predicting success among first-year engineering students at the Rand Afrikaans University. Psychological Reports, 93, 399-409.

15. Steyn, T.S., Maree, J.G. (2003). Study orientation in mathematics and thinking preferences of freshmen engineering and science students. Perspectives in Education, 21, 47-57.

16. Nthswanti-Khumalo, T. (2003). A tertiary update: October 2002 - September 2003. Edusource Data News, 42, 1-20.

17. Howie, S. (2001). Mathematics and science performance in Grade 8 in South Africa. 1998/1999. Pretoria: Human Sciences Research Council.

18. Maree, J.G., De Boer, A. (2003). Assessment of thinking style preferences and language proficiency for South African students whose native languages differ. Psychological Reports, 93, 449457.

19. Maree, J.G., Steyn, T.M. (2001). Diverse thinking-style preferences in a university course in mathematics. Psychological Reports, 89, 583-588.

20. Pollock, J.E., Wilkinson, B.L. (1988). Enrollment differences in academic achievement for university study skills students. College Student Journal, 22, 76-82.

21. Maree, J.G. (1999). Difference in orientation towards the study of mathematics of South African high school learners: developing a study orientation questionnaire in mathematics. Psychological Reports, 84, 467-476.

22. De Corte, E. (1995). Introducing schools to new perspectives on learning and teaching. Univer. of Pretoria.

23. Louw, C.J. (2003). The impact of tutorials on the mathematics achievement of students in first year mathematics. Unpublished master's dissertation, University of Pretoria.

24. Schoenfeld, A.H. (1985). Mathematical problem solving. New York: Academic Press.

25. Ramnarain, U. (2003). A strategies-based problem solving approach in the development of mathematical thinking. Pythagoras, 57, 32-35.

26. De Vries, A. (05.06.2005). Reuse-uittog knou townshipskole. Rapport, 20.

27. Uitgebreide veranderinge is aangebring aan die oorspronklike Kurrikulum 2005. Hierdie veranderinge is beliggaam in die Hersiene Nasionale Kurrikulumverklaring.

28. Kassiem, A. (26.05.2004). Grade 6 pupils can't read or write poll. Pretoria News, 2.

29. Dugmore in Kassiem, A. (26.05.2004). Grade 6 pupils can't read or write - poll. Pretoria News, 2.

30. Perry, H. (2003). Female performance in the senior certificate examination: excellence hiding behind the averages. Edusource Data News, 39, 14-25.

31. Maree, J.G., Prinsloo, W.B.J., Claassen, N.C.W. (1997). Handleiding vir die Studieoriëntasievraelys in wiskunde (SOW). Pretoria: Raad vir Geesteswetenskaplike Navorsing, pp. 1, 5-6.

32. Cohen, L., Manion, L., Morrison, K. (2001). Research methods in education (5th edition). London: Routledge.

33. McMillan, J.H., Schumacher, S. (2001). Research in education: A conceptual introduction (5th edition). New York: AddisonWesley Longman.

34. Carstens, M. (2005). Persoonlike mededeling, 19 Februarie 2004.

35. Maree, J.G., Prinsloo, W.B.J., Claassen, N.C.W. (1997), Handleiding vir die Studieoriëntasievraelys in wiskunde (SOW). Pretoria: Raad vir Geesteswetenskaplike Navorsing, pp. 1, 5-6.

36. Ibid.

37. Ibid.

38. Mulder, J.C. (1989). Statistiese tegnieke in opvoedkunde. 1ste uitgawe, 2de druk. Pretoria: Sigma-Pers., p.146,147.

39. Die leser word daarop gewys dat 'n lae telling in die Veld Wiskundeangs dui op meer wiskundeangs, terwyl 'n hoë telling weer dui op minder wiskundeangs.

40. Sharma, M.C. (1981). Using word problems to aid language and reading comprehension. Topics in Learning \& Learning Disabilities, 1(3), 61-71.

41. Rothman, R., Cohen, J. (1989). The language of math needs to be taught. Academic Therapy, 25, 133-142.

42. Sentson, C. (1994). The effect of language of presentation on pupils' performance in a mathematics test. South African Journal of Education, 14(3), 109-115.

43. Sibaya, P.T., Sibaya, D., Mugisha, R.X. (1996). Black secondary school pupils' problems with mathematical concepts. South African Journal of Education, 16(1), 32-37.

44. De Souza, C. (2003). Senior certificate exams 2002: plausible progress or passes below par? Edusource Data News, 39, 1-10.

45. Perry, H. (2003). Female performance in the senior certificate examination: excellence hiding behind the averages. Edusource Data News, 39, 14-25.

46. Vally, S. (1998). Poverty and inequality in education. Quarterly Review of Education and Training in South Africa, 5(4), 4-8.

47. Ibid.

48. Pandor, N. (2004). Maths today and tomorrow. Toespraak van Minister Naledi Pandor by geleentheid van die opening van die 9e Wiskundekongres (AMESA). Potchefstroom, 1 Julie 2005 49. Ibid 